\title{
Comparison of the Rules of Classification Societies (IACS Members) in the Area of Submersible Maneuvering
}

\author{
Oğuzhan Kirikbaş ${ }^{1 *}$, Şakir Bal ${ }^{2}$, M. Ali Baykal ${ }^{3}$ \\ 1* İstanbul Technical University, Faculty of Naval Architecture \& Ocean Engineering, İstanbul, Turkey, (ORCID: 0000-0002-2504-8727), kirikbas17@itu.edu.xtr \\ 2 İstanbul Technical University, Faculty of Naval Architecture \& Ocean Engineering, İstanbul, Turkey, (ORCID: 0000-0001-8688-8482), sbal@itu.edu.xtr \\ 3 İstanbul Gedik University, Departmant of Mechanical Engineering, İstanbul, Turkey, (ORCID: 0000-0003-2876-4232), mehmet.baykal@gedik.edu.tr;
}

(1st International Conference on Applied Engineering and Natural Sciences ICAENS 2021, November 1-3, 2021)

(DOI: $10.31590 /$ ejosat.993414)

ATIF/REFERENCE: Kırıkbaş, O., Bal, S. \& Baykal, M.A. (2021). Comparison of the Rules of Classification Societies (IACS Members) in the Area of Submersible Maneuvering. European Journal of Science and Technology, (28), $178-183$.

\begin{abstract}
The Classification Societies find their purpose of existence from the requirement of ensuring safety of merchant activities on seaways. This high-level requirement contains all the safety related aspects of cargo and passenger transportation as well as extraction of resources from seas/under seabed and renewable energy production from wind and waves. The scope of a Classification Society in that high-level requirement is limited on the platform and its systems. A few decades ago, this scope is even more limited and solely consists of activities, which were performed on sea surface. Increasing dependency on the resources under the ocean floor, emergence concept of underwater cargo transportation and developing industry of tourist submarine cruises enlarged this scope. As a consequence of this "underwater" rules were developed by Classification Societies. These rules are mostly the adapted versions of the surface rules. They generally consist of strength, reliability and redundancy of the platform and its systems. However, maneuvering is not directly mentioned in the current versions of the underwater rules. On contrary to the surface vessels maneuvering characteristics can have vital consequences on the safety of underwater vehicle. The reason behind this, is the additional 2-DOF that a submersible has in the vertical plane. This paper is aiming to summarize the current status of the rules on submersible maneuvering of the Classification Societies that are members of IACS (International Association of Classification Societies). Then the existing rules were categorized. A comparison was made between Classification Societies for each of the rule to come out a conclusion about the maturity and commonality level of each category.
\end{abstract}

Keywords: Classification Society, Classification Rules, Maneuvering, Dynamic Stability, Submersible.

\section{IACS Üyesi Klas Kuruluşarının Su Altı Aracı Manevrası Alanına İlişkin Kurallarının Karşılaştırılması}

$\ddot{O} \mathbf{z}$

Klas Kuruluşlarının varlık amaçları, deniz yollarında ticari faaliyetlerin güvenliğini sağlama gerekliliğinden kaynaklanmaktadır. Bu üst düzey gereklilik, yük ve yolcu taşımacılığının yanı sıra denizlerden/deniz tabanından kaynakların çıkarılmasını ve rüzgar ve dalgalardan yenilenebilir enerji üretiminin güvenlikle ilgili tüm yönlerinin kapsar. Bir Klas Kuruluşunun bahse konu üst düzey gerekliliğin yerine getirilmesine ilişkin sorumluluğu platform ve sistemleriyle sınırlıdır. Geçmişte bu kapsam daha da sınırlıydı ve yalnızca deniz yüzeyinde gerçekleştirilen faaliyetleri kapsamaktaydı. Deniz tabanının altındaki kaynaklara olan bağımlılığın artması, su altı yük taşımacılığı kavramının ortaya çıkması ve gelişen turistik denizaltı endüstrisi bu kapsamın genişlemesine sebep olmuştur. Bunun bir sonucu olarak, Klas Kuruluşları tarafından "sualtı” kuralları geliştirilmiştir. Bu kurallar çoğunlukla yüzey kurallarının uyarlanmış versiyonlarıdır. Genellikle bu kurallar platformun ve sistemlerinin dayanıklılığı, güvenilirliğgi ve yedeklenebilirliği kavramları üzerine inşa edilmişlerdir. $\mathrm{Bu}$ kurallarının güncel versiyonlarında manevra kavramına çoğunlukla doğrudan değinilmemektedir. Su üstü gemilerinin aksine manevra özellikleri, su altı araçlarının güvenliği üzerinde hayati sonuçlar doğurabilir. Bunun nedeni, bir su altı aracının düşey düzlemde sahip olduğu ilave iki serbestlik derecesidir. Bu çalışma, IACS (International Association of Classification Societies-Uluslararası Klas Kuruluşları Birliği) üyesi olan Klas Kuruluşlarının su altı aracı manevralarına ilişkin kuralların mevcut durumunu özetlemeyi amaçlamaktadır. Daha sonra mevcut kurallar kategorize edilmiş, her bir kategorinin gelişmişlik ve benzerlik düzeyi hakkında bir sonuca varmak için Klas Kuruluşları arasında kural bazında bir karşılaştırma yapılmıştır.

Anahtar Kelimeler: Klas Kuruluşu, Klas Kuruluşu Kuralları, Manevra, Dinamik Stabilite, Su Altı Aracı.

* Corresponding Author: kirikbas17@itu.edu.xtr 


\section{Introduction}

"Safety first" is a highly adopted motto for all kind of maritime operations. When the vessel and its main systems are concerned, the Classification Societies carry out this motto.

This mission is not limited to the new buildings. Classification societies also get involved in other milestone topics of ship lifecycle into different extents. This involvement is done via class rules established by societies for drawing a frame of minimum requirements. The scope of these rules are mainly the strength, reliability and redundancy of the vehicle and its vital systems. For instance, nearly all of the societies necessitates a proof of midsection strength of a ship through investigation of the sizing of structural components. By doing this they get involved in the ship's life cycle at a very early design stage. Other topics such as maneuvering may attract the society's attention indirectly. The rules regarding such topics are only considered by means of its effects on the above-mentioned notions of the final product.

Being adapted from the surface vessel rules, this situation is also valid for the underwater rules for maneuvering. Moreover, until the last few decades underwater operations attracted much less attention due to their technical and financial difficulties.

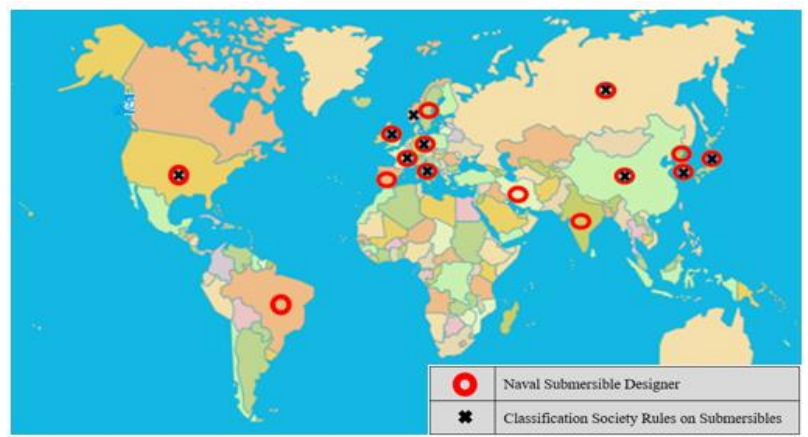

Fig. 1 Countries of naval submarine designers and having "underwater" class rules

Consequently a few nations have underwater rules. Since the pioneer and end user of the underwater technologies are mostly the navies, these nations are the main naval submarine designer and operators as one can clearly observe from Figure 1. It is shown in Figure 1 and Table 1 that the countries, which are capable of designing naval submarines, have "underwater" class rules. Out of nine societies from 12 IACS members have the rules regarding submersible vehicles.

Table 1. List of members of IACS and their status of rules for the classification of UVW

\begin{tabular}{|l|c|}
\hline Classification Society & Rules Exist/ Not Exist \\
\hline ABS (2021) & $\checkmark$ \\
\hline BV (2018) & $\checkmark$ \\
\hline CCS (2018) & $\checkmark$ \\
\hline CRS & X \\
\hline DNV-GL (2018) & $\checkmark$ \\
\hline IRS & X \\
\hline KRS (2021) & $\checkmark$ \\
\hline LR (2020) & $\checkmark$ \\
\hline Class NK (2020) & $\checkmark$ \\
\hline PRS & X \\
\hline RINA (2011) & $\checkmark$ \\
\hline RMRS (2004) & $\checkmark$ \\
\hline
\end{tabular}

The evolution of underwater rules is also nurturing by the growing utilization of underwater vehicles for non-military purposes (i.e. merchant, scientific, leisure etc.). Examples of these type of vehicles are shown in Figure 2, 3 and 4. Classification societies are forced to regulate also this area of operation by generation of subcategories dedicated to each vessel type (tourist submersible, AUVs/ROVs, vessels for underwater cargo transportation etc.)

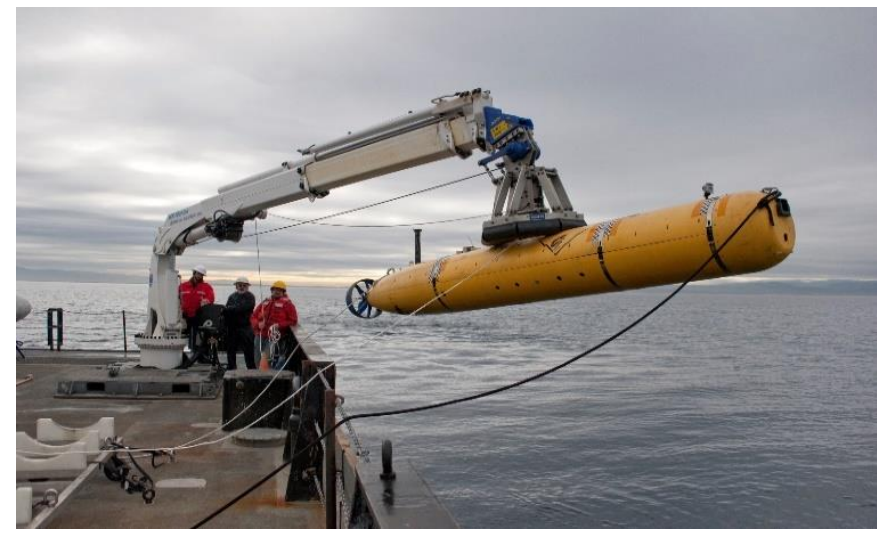

Fig. 2 An AUV

The knowledge required to design such vessels can be considered as a byproduct of the design experience of major naval subsea systems.

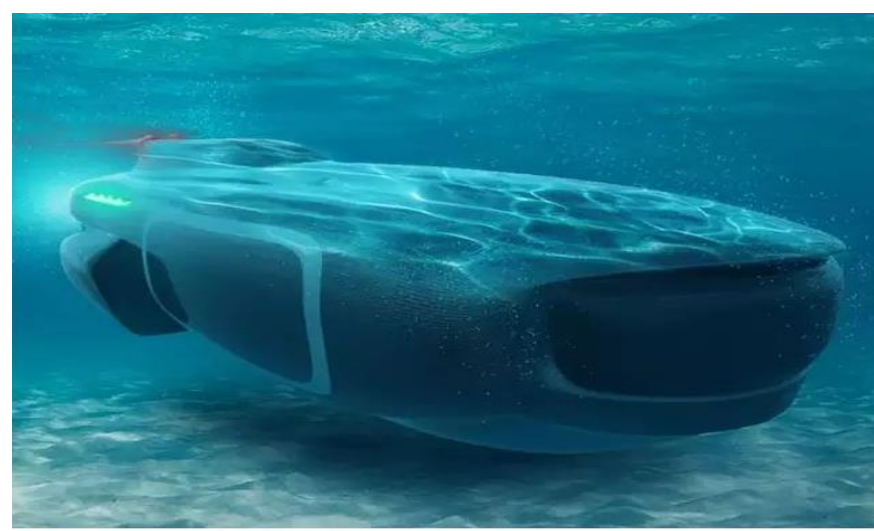

Fig. 3 A cargo submarine concept

Consequently, these systems are generally designed by the leading nations in the area of naval subsea systems design. The class rules dedicated to non-military applications are again developed by classification societies of these nations. 


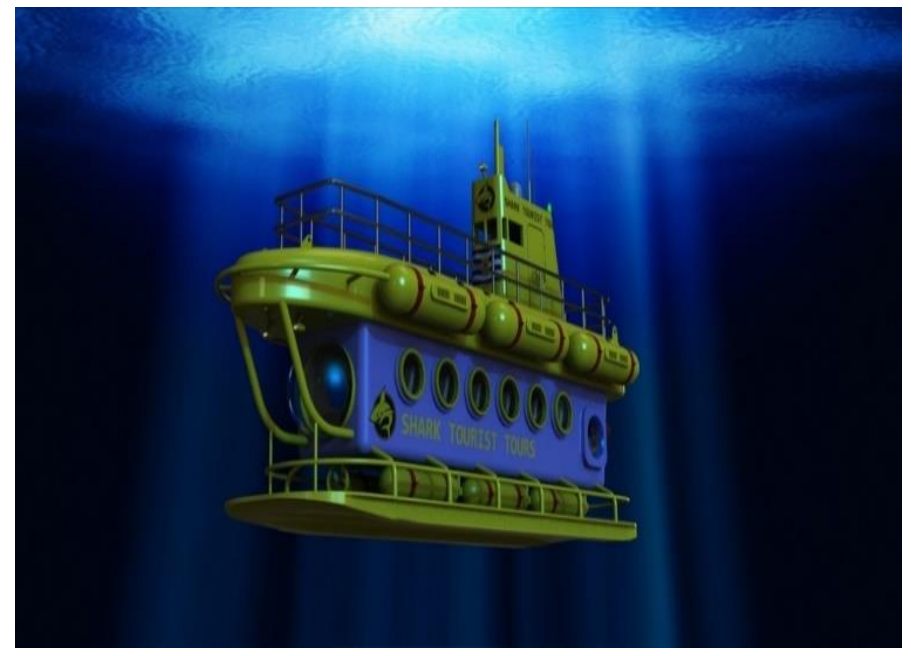

Fig. 4 A tourist submarine concept

The structure of the underwater rules of the classification societies mentioned in Table 1 can be generalized as in Figure 5.

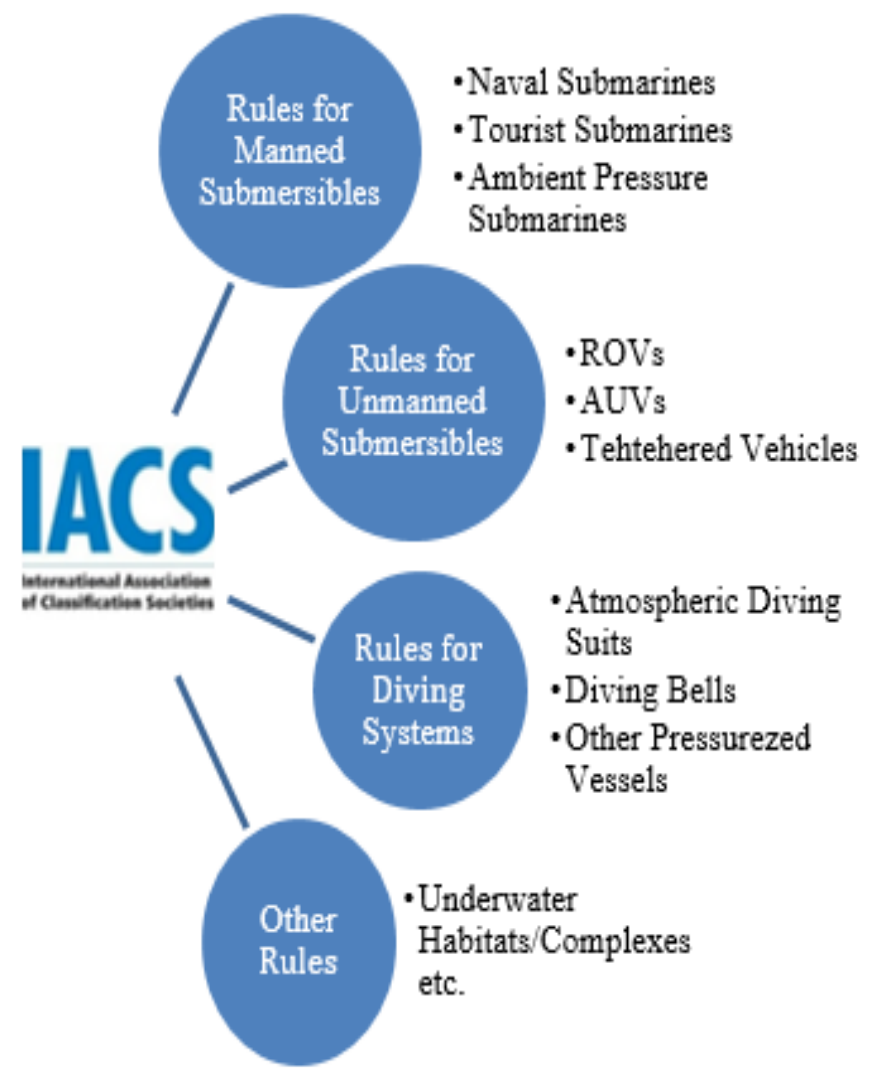

Fig. 5 The structure of rules of the Classification Societies

As a thumb rule on Manoeuvring is contained in the category of "Manned Submersibles". If exists, the rules for other type of vessels contain only the deviations from this category.

\section{Material and Method}

In the scope of "maneuvering", the underwater rules of classification societies can be categorized into three main topics according to method of proof of their requirements. Then rules in each category can be compared between Classification Societies. Because different classification societies use different wording and emphasize different aspect of the same issue in their rules, word-by-word comparison of the rules is not practical and even e-ISSN: 2148-2683 not possible. Rather than that, the enlarged meaning of the text is compared. These categories are namely,

$>$ Proof by investigating design documentation and drawings.

$>$ Proof by performing test and trials.

$>$ Proof by performing calculations and simulations.

\section{Results and Discussion}

Rules in the first two categories are similar for different classification societies. The reasons behind the analogy among societies about these categories are:

$>$ For the classification phase to recognize the vessel, the minimum required design documentation/drawings are well defined.

$>$ After completion, testing the final product to its limits is an accepted industrial practice for any engineering products.

Details of the comparison can be found in the following subsections.

\subsection{Proof By Design Documentation And Drawings}

The scope and content of the rules which requirements are fulfilled by submitting design documentation, are summarized in Table 2 .

Table 2 Comparison of the maneuvering rules (design documentation and drawings)

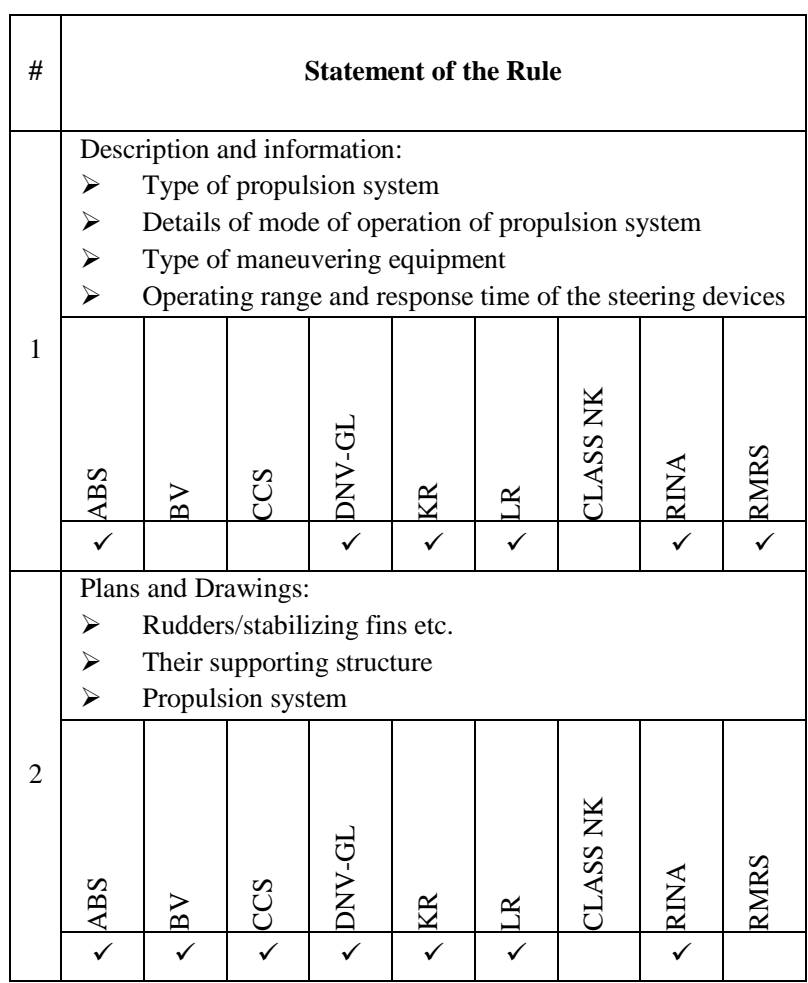

\subsection{Proof by test and trials}

According to the test plan approved by society, testing can be done for each of the equipment in factory level but a final test dive as well as surface cruising test is mandatory. In the rules of CCS, the test dive phase is also divided into shallow and deep-water tests explicitly. This must also be a common practice for the other societies for safety reasons but not explicitly mentioned in their rules. The results of this test and trials shall be submitted to the 
societies as a rule. This rule applies also for the model tests (if done any) for some of the societies. The scope and content of the rules which's requirements are fulfilled by test and trials are summarized in Table 3.

Table 3 Comparison of the maneuvering rules (test and trials)

\begin{tabular}{|c|c|c|c|c|c|c|c|c|c|}
\hline \# & \multicolumn{9}{|c|}{ Statement of the Rule } \\
\hline \multirow[t]{3}{*}{1} & \multicolumn{9}{|c|}{$\begin{array}{ll}\text { Submerged Tests: } \\
\quad \text { Functional efficiency of maneuvering and control equipment } \\
>\quad \text { Functional test of propulsion plant } \\
>\quad \text { Stopping tests for different speeds ahead. } \\
>\quad \text { Installation of propelling and maneuvering equipment by means of; } \\
\quad \quad \quad \text { Z maneuver } \\
\quad \quad \quad \text { Turning circle } \\
\\
>\quad \text { Pitch of rudders and planes at maximum speed. }\end{array}$} \\
\hline & 華 & $\vec{D}$ & $\tilde{U}$ & $\begin{array}{l}\overrightarrow{0} \\
\text { 方 } \\
\text { za }\end{array}$ & $\underline{v}$ & 믹 & 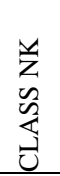 & $\underset{\Omega}{\mathbb{\Omega}}$ & $\sum_{\underline{\underline{n}}}^{\tilde{n}}$ \\
\hline & & $\checkmark$ & $\checkmark$ & $\checkmark$ & $\vec{v}$ & $\vec{v}$ & $\checkmark$ & $\checkmark$ & $\checkmark$ \\
\hline \multirow{3}{*}{2} & \multicolumn{9}{|c|}{$\begin{array}{l}\text { Surface Tests: } \\
>\quad \text { Functional test of propulsion plant } \\
>\quad \text { Installation of propelling and maneuvering equipment by means of; } \\
\quad \quad \quad \mathrm{Z} \text { maneuver } \\
\circ \quad \text { Turning circle } \\
>\quad \text { Pitch of rudders and planes at maximum speed. }\end{array}$} \\
\hline & 党 & m & U & $\begin{array}{l}0 \\
1 \\
z \\
z\end{array}$ & $\frac{1}{x}$ & 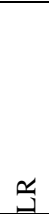 & 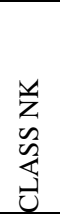 & $\underset{\underline{\underline{z}}}{\overleftrightarrow{\mathbb{Z}}}$ & $\sum_{\underline{\underline{x}}}^{\mathscr{n}}$ \\
\hline & & $\checkmark$ & $\mathrm{v}$ & I & & & $\checkmark$ & & \\
\hline
\end{tabular}

\subsection{Proof by calculations and simulations}

The varsity show itself in terms of rules, which's requirements have to be proven with calculations and/or simulations. Since maneuvering is a topic, which is not well understood as structural integrity the societies prefer to establish rules regarding this topic in general terms, covering several aspects of the design at once. This requires performing of several calculations/simulations for proof. The rules often do not contain any specific requirements expressed numerically. Rather, the requirements are generally in the form of "under a defined condition the vessel or system may have the ability to meet a specific requirement". In order to take the worst-case scenario for the normal operating condition into account, this "specific condition" is generally the maximum speed and control surface angle. The scope and content of some important rules which's requirements are fulfilled by calculations and simulations summarized in Table 4.
Table 4 Comparison of the maneuvering rules (calculations and simulations)

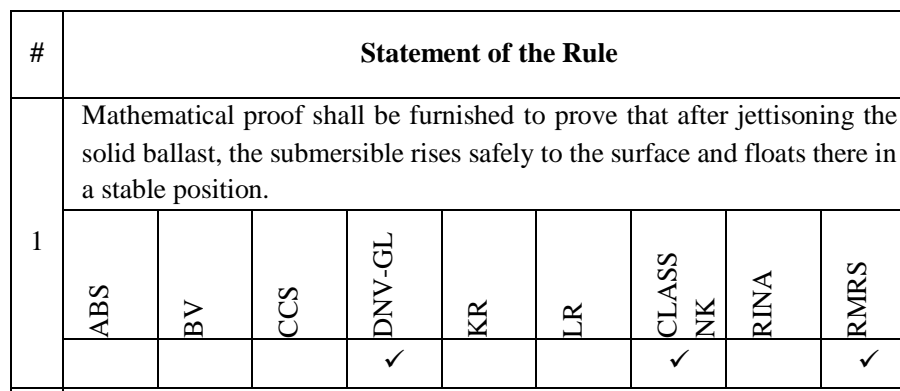

With the submarine traveling at full speed, the steering gear shall be capable of putting the vertical rudder from $35^{\circ}$ on one side to $35^{\circ}$ on the other side within the specified time values for surfaced and submerged condition. An emergency steering device shall be provided. Note: the time shall not be more than 28 seconds.

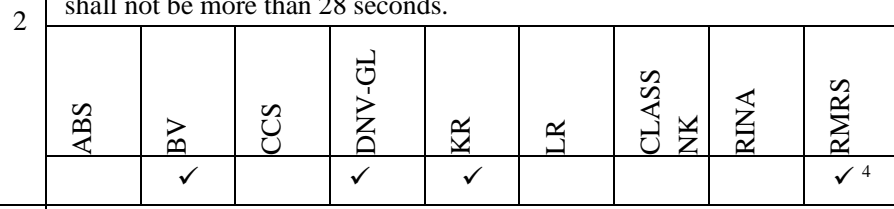

Operation manuals which include the following items are to be provided on board to ensure the safety of the submersible and one set of copies is to be submitted to the Society

Maximum speed and limits of trim in both surface and underwater

3 conditions and crash astern performance.

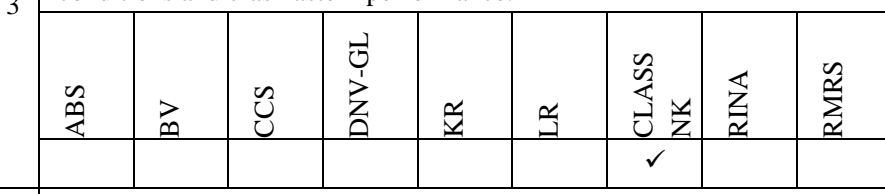

A FMEA showing a safety envelope for NDD in a relation to the submarine velocity. The propulsion and maneuvering equipment are relevant for FMEA analysis. The FMEA shall contain a summary of the results of the analysis for the relevant submarine and especially for keeping the maneuverability and ability for surfacing. The following cases have to be investigated.

4

Jamming of hydroplanes at maximum angle Partly flooding

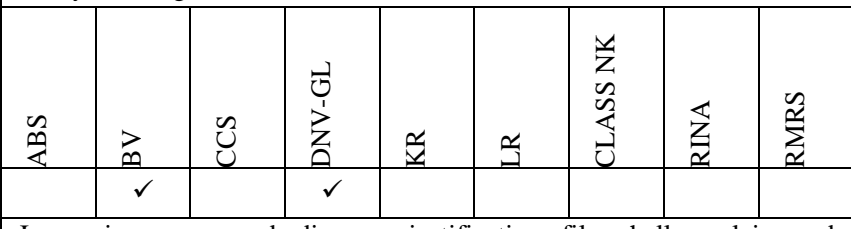

Immersion vs. speed diagram justification file shall explain and demonstrate that submitted cases of sea water leakage and loss of maneuvering means scenarios won't lead the submarine to dive over extreme immersion and reach unacceptable climbing speed or trim or list during the submarine's way up to the surface of the sea. Specific hypothesis shall be mentioned.

$>$ Initial situation of submarine (immersion, speed, way, trim, unavailable equipment before failure if any)

timing and details of reactions of the crew and equipment responses

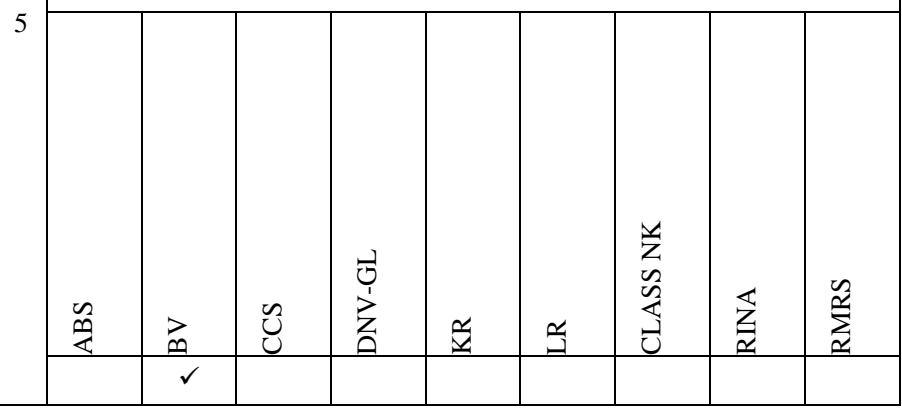




\subsection{Discussion}

Evolution of underwater class rules is discussed. The underwater rules of major classification societies on submersible Maneuvering is compared under different subcategories.

The rules which contain requirements that need to be fulfilled either test and trials or document submission, are observed to be mature enough. These rules are almost common for all of the classification societies.

This cannot be claimed for rules which requirements are needed to be satisfied by calculations or simulations. As can be seen in Table 4, the rules matrix is sparse. This means that the maturity and commonality level of rules are both inadequate.

Designing complex system such as submersibles requires vast number of calculations/simulations to be performed. These analyses must be done for each new building with no doubt. Additionally, the submission/approval of the principal ones should be requested by Classification Societies even if they are not specifically mentioned in their rules.

For instance, dynamic stability is a well-known concern for underwater vehicles. To ensure the maneuvering safety of the vehicle designer as well as the Classification Society must be confident at least about the stability in the vertical plane. This can be done by calculation of the stability of indice by using stability derivatives of the vehicle and comparing them with the threshold values which can be fined in the literature.

$$
G_{V}=1-\frac{M_{w}{ }^{\prime}\left(Z_{q}{ }^{\prime}+m^{\prime}\right)}{Z_{W}{ }^{\prime}\left(M_{q}{ }^{\prime}-x_{G}{ }^{\prime} m^{\prime}\right)}
$$

where;

\section{$G_{V} \quad$ Vertical stability indices}

$m^{\prime} \quad$ Non-dimensional mass

$x_{G}{ }^{\prime} \quad$ Longitudinal center of gravity

$M_{w}{ }^{\prime} \quad$ Non-dimensional coefficient used in representing pitching moment as a function of heave velocity.

$M_{q}{ }^{\prime}$ Non-dimensional coefficient used in representing pitching moment as a function of pitch velocity.

$Z_{q}{ }^{\prime} \quad$ Non-dimensional coefficient used in representing heave force as a function of pitching velocity.

$Z_{w}{ }^{\prime}$ Non-dimensional coefficient used in representing heave force as a function of heave velocity.

Table 5. Vertical stability indices range vs. degree of stability (Feldman, 1995)

\begin{tabular}{|l|l|}
\hline Gv Range & Degree of Stability \\
\hline 0.0 to 0.2 & Marginally Stable \\
\hline 0.5 to 0.7 & Good Dynamic Performance \\
\hline$\geq 0.8$ & Highly Stable \\
\hline
\end{tabular}

Although the above-mentioned process is a common practice, none of the classification society established a rule regarding these threshold values. This prevents the standardization and cause a lack of guidance for the designers.

\section{Conclusions and Recommendations}

The underwater rules of the several classification societies about the topic of "maneuvering" are examined and compared with each other. The results can be summarized as follows:

$>$ Rules of different Classification Societies of maneuvering can be categorized into three topics according to their methods of fulfillment. For the rules, which required to be satisfied by submission of drawings/documentation and by tests/trials, the societies have common understandings. Their requirements are very similar for these two categories.

$>$ For the rules which require the simulations/calculations to be made, there are much more diversity between the societies.

$>$ Although vast amount of calculations and simulation must be made during the design phase of the vehicle and some of them is used as a proof of fulfillment of the rules, there are still no numerically defined criteria in the class rules that can guide a designer in terms of maneuvering characteristics during the initial design phases.

In the near future, the concept of utilization of multiple UUV's together and in combination with a mother submarine will be realized. This concept requires a different level of safety because of the high risk of collision. Moreover, utilization of submersibles for leisure activities is also gaining a popularity. Tourist submersibles become more capable about diving and maneuvering in order to respond the demands of customers. Their numbers are also increasing in each area of operation. Considering these aspects together; Classification Societies shall develop more specific maneuvering rules for submersible vehicles to comply with these difficulties.

In parallel with the world-wide applications, utilization of submersibles is also gaining a popularity in Turkey. Considering its growing touristic potential and interest on hydrocarbon extraction under seabed, the number of submersibles operated in Turkish territorial waters and neighboring open seas has a potential of rapid increment. These vessels will need classification upon completion and annually afterwards. Moreover, Turkey has the intention of performing the design and integration of a naval submarine by solely relying on its own sources including classification phase for the sake of confidentiality. These facts, while considered together, led to the result that Turkish Lloyd (not a member of IACS) has to build a solid knowledge in submersible classification and gain ability to guide the designers with its rules.

\section{References}

American Bureau for Shipping (ABS), Rules for building and classing Underwater vehicles, systems and hyperbaric Facilities, January 2021, available at: https://ww2.eagle. org/content/dam/eagle/rules-and-guides/current/ special_service/7_rulesforbuildingandclassingunderwaterve hiclessystemsandhyperbaricfacilities_2021/uwvs-rulesjan21.pdf [accessed 04 May 2021].

Bureau Veritas (BV), Rules for the Classification of Naval Submarines", September 2018, available at: https://marineoffshore.bureauveritas.com/nr535-rules-classification-navalsubmarines [accessed 04 May 2021].

China Classification Society (CCS), Rules For Classification of Diving Systems and Submersibles, December 2018, available at: $\quad$ https://www.ccs.org.cn/ccswzen/specialDetail? $\mathrm{id}=$ 201910000000003438 [accessed 04 May 2021]. 
Det Norske Veritas (DNV), Rules for classification Underwater Technology Edition Part 5 Types of UWT Systems Chapter 6 Manned Submersibles, January 2018, available at: https://rules.dnv.com/ServiceDocuments/dnv/\#!/industry/1/ Maritime/5/Rules\%20for\%20classification:\%20Underwater \%20technology\%20(RU-UWT) [accessed 04 May 2021].

Feldman, J. P. (1995). Method of Performing Captive-Model Experiments to predict the Stability and Control Characteristics of Submarines. Naval Surface Warfare Center Carderock Division, Bethesda, MD.

Korean Register of Shipping (KRS) Rules and Guidance for the Classification of Underwater Vehicles, 2021, available at: https://eclass.krs.co.kr/KRRules/KRRules2016/data/DATA OTHER/ENGLISH/ rb05e000.pdf [accessed 04 May 2021].

Lloyd's Register (LR), Rules and Regulations for the Construction \& Classification of Submersibles \& Diving Systems, July 2020, available at: https://www.lr.org/en/rulesfor-submersibles/ [accessed 04 May 2021].
Nippon Kaui Kyakai (ClassNK), Rules for the Survey and Construction of Steel Ships Contents-Part T Submersibles, 2020, available at: https:/www.classnk.or.jp/account/en/ Rules_Guidance/ssl/tech_rules.aspx [accessed 04 May 2021].

Registro Italiano Navale (RINA), Rules for the Classification of Underwater Units, January 2011, available at: https://membermarine.rina.org/content/rg [accessed 17 May 2021].

Russian Maritime Register of Shipping (RMRS), Rules for the Classification and Construction of Manned Submersibles, Ship's Diving Systems and Passenger Submersibles, November 2004, available at: https://rsclass.org/forms/view.php?pdf=/upload/iblock/898/89898a25 5ffa405ede564077a6e59f45.pdf [accessed 04 May 2021]. 